\title{
Phosphates diversity and development in Conțu pegmatites, Cindrel Mountains, Romania
}

\author{
Nicolae CĂLin ${ }^{1}$, Delia-GeORgeta Dumitraș, \\ GEORGE CĂTĂLIN SIMION, ȘTEFAN MARINCEA, \\ ADRIANA-MARIANA ION, CIPRIAN CONSTANTINA, \\ INGRID POLL, AURORA MĂRUȚA IANCU, CRISTINA SAVA \\ 1'nicolae_cln@yahoo.com
}

The aim of this study is to show the diversity and development of phosphate from Conțu pegmatites fields, located in Superior and Inferior Conțu, surrounded by gneisses, micaschists and amphibolite. The main minerals are: albite (cleavelandite), green spodumene, smoky quartz, muscovite; with accesory minerals "Quensel-Mason" sequence minerals: green triphylite, brown ferrisicklerite and purple heterosite; wolfeite, maricite, vivianite, fluorapatite, hidroxylapatite, monazite, "ferrogatehouseite", ambligonite montebrasite; K-feldspar - microcline, cassiterite, tourmaline (schorl), uraninite, columbite - tantalite, sillimanite, biotite, titanite, beryl. The first stage of hydrotermal transformation shows the oxidation of the primary phosphate - triphylite $\left(\mathrm{Li}_{0.998} \mathrm{Ca}_{0.001}\right)_{0.999}\left(\mathrm{Fe}_{0.654} \mathrm{Mn}_{0.324} \mathrm{Mg}_{0.009}\right)_{0.987} \mathrm{PO}_{4}$, and, then the loss of $\mathrm{Li}$ amount leads to the appearance of ferrisicklerite $\left(\mathrm{Li}_{0.956} \mathrm{Ca}_{0.021}\right)_{0.978} \quad\left(\mathrm{Fe}_{0.650} \mathrm{Mn}_{0.392} \mathrm{Mg}_{0.005}\right)_{1.048}$ $\mathrm{PO}_{4}$; in the late hydrothermal stage of pegmatite, heterosite $\mathrm{Ca}_{0.056}\left(\mathrm{Fe}^{3+}{ }_{0.622} \mathrm{Mn}^{3+}{ }_{0.391} \mathrm{Mg}^{2+}{ }_{0.005}\right)_{1.019} \mathrm{PO}_{4}$ and vivianite $\mathrm{Fe}^{2+}\left(\mathrm{PO}_{4}\right)_{2} * 8 \mathrm{H}_{2} \mathrm{O}$ are formed. Uraninite $\mathrm{UO}_{2}$ indicating $\mathrm{U}=$ $2.201 \mathrm{ppm}$ and sillimanite also coresponds to late hydrotermal transformation stage. Montebrasite - ambligonite and heterosite are replaced by apatite, we found fluorapatite $\left(\mathrm{Ca}_{4.862} \mathrm{Na}_{0.054}\right)_{4.916}\left(\mathrm{Fe}_{0.060} \mathrm{Mn}_{0.165} \mathrm{Mg}_{0.001}\right)_{0.226}\left(\mathrm{~F}_{0.735} \mathrm{OH}_{0.264}\right)_{0.99}$ ${ }_{9}\left(\mathrm{PO}_{4}\right)_{3}$ and hidroxylapatite $\left(\mathrm{Ca}_{3.360} \mathrm{Na}_{0.335}\right)_{3.695}\left(\mathrm{Fe}_{0.497} \mathrm{Mn}_{0.636}\right.$ $\left.\mathrm{Mg}_{0.005}\right)_{1.138}\left(\mathrm{OH}_{0.709} \mathrm{~F}_{0.291}\right)_{1.00}\left(\mathrm{PO}_{4}\right)_{3}$, certainly, they were formed by the $\mathrm{H}_{2} \mathrm{O}$ and $\mathrm{F}$ enrichments. Wolfeite $\mathrm{Ca}_{0.033}\left(\mathrm{Fe}_{1.155} \mathrm{Mn}_{0.791} \mathrm{Mg}_{0.003}\right)_{1.949}(\mathrm{OH})_{1.00} \mathrm{PO}_{4} \quad$ and "ferrogatehouseite" $\quad \mathrm{Ca}_{0.002}\left(\mathrm{Fe}_{3.601} \mathrm{Mn}_{1.355} \mathrm{Mg}_{0.024}\right)_{4.980}\left(\mathrm{PO}_{4}\right)_{2}$ $(\mathrm{OH})_{4}$ appears as inclusions in a centimetric nests of triphylite. Maricite $\left(\mathrm{Na}_{0.932} \mathrm{Ca}_{0.008}\right)_{0.940}\left(\mathrm{Fe}_{0.623} \mathrm{Mn}_{0.378} \mathrm{Mg}_{0.002}\right)$ ${ }_{1.003} \mathrm{PO}_{4}$ appears in the mass of ferrisicklerite and heterosite. Presence of $\mathrm{Fe}^{2+}$ in comparison with $\mathrm{Fe}^{3+}$ is high, showing us one unique "Quensel - Mason" sequence for Conțu pegmatites; $\mathrm{Fe}^{2+}$ predominates in green beryl intimately associated with quartz and in tourmaline (schorl). It is possible that phosphates from this pegmatites are included in rare element pegmatites; and belonging to NYF and mixed (NYF - LCT) family, class of rare - element pegmatites, albite and spodumene type, as well as complex type, subclass REL-Li and REL-REE (Černý and Ercit 2005). 